
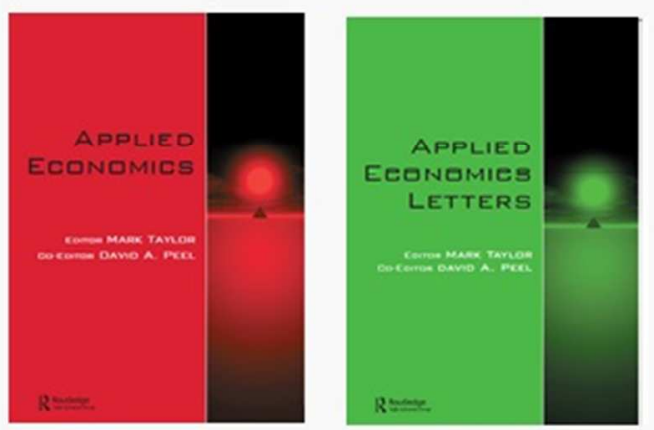

\title{
The long-run causal relationship between exports and economic growth in the Euro Area
}

\begin{tabular}{|r|l|}
\hline Journal: & Applied Economics \\
\hline Manuscript ID & Draft \\
\hline Journal Selection: & $\begin{array}{l}\text { Applied Economics Letters incorporating Applied Financial Economics } \\
\text { Letters }\end{array}$ \\
\hline Complete List of Authors: & $\begin{array}{l}\text { Konstantakopoulou, Ioanna; Centre for Planning and Economic Research, } \\
\text { Economics } \\
\text { Tsionas, Mike; Lancaster University, of Economics }\end{array}$ \\
\hline JEL Code: & $\begin{array}{l}\text { COO - General < CO - General < C - Mathematical and Quantitative } \\
\text { Methods, F43 - Economic Growth of Open Economies < F4 - } \\
\text { Macroeconomic Aspects of International Trade and Finance < F - } \\
\text { International Economics }\end{array}$ \\
\hline Keywords: & $\begin{array}{l}\text { EXPORTS, Cross-sectional dependence, Economic growth, Heterogeneous } \\
\text { panels }\end{array}$ \\
\hline \multicolumn{2}{|c}{} \\
\hline
\end{tabular}

\section{SCHOLARONE"}

Manuscripts 


\title{
The long-run causal relationship between exports and economic growth in the Euro Area
}

\author{
By \\ Ioanna Konstantakopoulou ${ }^{1}$ and
}

Mike G. Tsionas ${ }^{2}$

\begin{abstract}
This article employs panel methods that mitigate heterogeneity and cross-sectional dependence to determine the direction and sign of long run causality between exports and economic growth in the euro area economies from 2000 to 2014 . The empirical evidence indicates that there is a unidirectional long run Granger causality relationship from exports to economic growth in the euro area countries.
\end{abstract}

Keywords: Exports, Economic growth, Panel Granger causality, Cross-sectional dependence, Heterogeneous panels

JEL Classification: C10; E0; F43

\footnotetext{
${ }^{1}$ Corresponding author. Centre for Planning and Economic Research, Address: 11 Amerikis Street, 10672 Athens, Greece. E-mail addresses: joannapk@aueb.gr.

2, Lancaster University Management School LA1 4YX, m.tsionas@lancaster.ac.uk; Department of Economics, Athens University of Economics and Business, 76 Patission Str., 10434 Athens, Greece.
} 


\section{Introduction}

Since the 1970s, many studies (Michaely 1977, Balassa 1978, and Feder 1982) have established exports as an engine of growth-driving in developing countries, applying correlation and regression techniques. The next wave of research (Jung and Marshall 1985, and Ahmed and Kwan 1991) focused on detecting the direction of the causal relationship between exports and economic growth. The launch of interest for the investigation of the export-led-growth hypothesis on developed country was mainly due to the work of Kunst and Marin (1989), Konya (2006), and Konstantakopoulou (2016) using causality and cointegration methods. Several theoretical arguments support the beneficial effects of exports on economic growth (Grossman and Helpman 1991, and Helpman and Krugman 1985), and advocate the exports-oriented policies (Bhagawati and Srinivasan 1978, and Bhagawati 1988).

In this paper, we apply the Canning and Pedroni (2008) procedure (hereafter CP) to infer the direction and sign of the long run causality relationship between exports and economic growth for euro area economies. This methodology offers the following advantages: First, by exploiting the panel structure power is increased, and secondly heterogeneity and shortrun dynamics across countries are allowed, while it is robust to endogeneity and omitted variable bias. We apply this procedure because of the aggregate variables seems to be heterogeneous and cross-sectionally correlated. This methodology has not been applied in the literature and the sample period that includes the recent crisis in the euro area. It is therefore of interest to policy-making concerning the promotion of export-led policies.

The paper is structured as follows. Section 2 presents data and methodology. Our empirical results are reported in Section 3. Section 4 outlines the results.

\section{Data and methodology}

Annual data on real exports and real GDP are supplied by the World Development Indicators of the World Bank for the period 1970-2014. The sample includes the Euro Area countries (EA12): Austria, Belgium, Finland, France, Germany, Greece, Ireland, Italy, Luxembourg, Netherlands, Portugal, and Spain. All variables are in natural logs.

The implementation of the CP methodology includes several tests, such as panel unit root test, panel cointegration test, panel causality test, and the estimation of panel average elasticity through the common correlated effects mean group (CMG) estimator of Pesaran (2006). 


\subsection{Heterogeneous panel causality procedure}

Based on the Granger representation theorem, if exports and economic growth are cointegrated, then there exists a valid error correction representation (ECM) of the data. Hence, we construct a dynamic ECM. Having estimated the cointegrating equation for each country through the FMOLS estimator, we can estimate the following dynamic ECM:

$$
\begin{aligned}
& \Delta e x_{i t}=c_{1 i}+\lambda_{1 i} \hat{e}_{i t-1}+\sum_{j=1}^{K_{i}^{1}} \varphi_{11 i j} \Delta e x_{i, t-j}+\sum_{j=1}^{K_{i}^{1}} \varphi_{12 i j} \Delta y_{i, t-j}+\varepsilon_{1 \mathrm{it}} \\
& \Delta y_{i t}=c_{2 i}+\lambda_{2 i} \hat{e}_{i t-1}+\sum_{j=1}^{K_{i}^{2}} \varphi_{21 i j} \Delta \mathrm{ex}_{\mathrm{i}, \mathrm{t}-\mathrm{j}}+\sum_{j=1}^{K_{i}^{2}} \varphi_{22 i j} \Delta y_{i, t-j}+\varepsilon_{2 \mathrm{it}}
\end{aligned}
$$

where $e x_{i t}$ is the real exports, $y_{i t}$ is the real GDP, $K$ is a country-specific lag length, the subscripts $i$ and $t$ denote country and the th the period, $\Delta$ is the first difference operator, $\lambda_{1 i}$ ,$\lambda_{2 i}$ are the speeds of adjustment coefficients, and $\hat{e}_{i t-1}$ is the one period lag of the residuals ( $\hat{e}_{1 t}=e x_{i t}-\hat{a}_{1 i}-\hat{b}_{t}-\hat{\beta}_{1 i} y_{i t}$, and $\left.\hat{e}_{2 i}=y_{i t}-\hat{a}_{2 i}-\hat{b}_{t}-\hat{\beta}_{2 i} e x_{i t}\right)$ from the long-run cointegrating relationships. Given that all the variables in equation system (1) are stationary, we can apply standard hypothesis tests on the coefficients. To identify the existence, of any long run causal effects running from exports to economic growth for any one country, we should be test the significance of $\lambda_{2 i}$. Therefore, tests on $\lambda_{2 i}\left(\lambda_{1 i}\right)$ in any given country can be interpreted, as tests of whether shocks to exports (economic growth) have a long run effect on economic growth (exports). The null hypothesis is that no panel Granger causality. They constructed two panelbased statistical tests based on country-by-country ECM estimations, i.e. a group mean test (GM) and a lambda-Pearson based (LP) test. Specifically, the GM test is based on the average of each individual country $\lambda_{2 i}$ tests and can be provide the ability to examine the direction of whether the long run causal effect is zero on average for the panel. Furthermore, the GM panel test has a standard normal distribution under the null hypothesis of no long-run causal effect from exports to economic growth. On the other hand, the LP panel test statistic uses a chi-square distribution under the null hypothesis of no long-run causal effect for the panel. When the GM test fails to reject, but the LP test does reject the null hypothesis (no Granger causality), we find evidence that Grangercausality is heterogeneous in the panel.

\section{Empirical results}

\subsection{Panel unit root tests}


To test for stationarity, we apply two panel unit root tests (first generation PURTs) developed by Levin, Lin and Chu (2002) - hereafter the LLC test, and the IPS test of Im, Pesaran, and Shin (2003). These tests have non-stationarity as the null hypothesis. The results of the PURTs for each variable are shown in Table 1. We fail to reject the null hypothesis for all variables in levels, but we reject it for their first differences. However, these tests assumed that the individual time series in the panel were cross-sectionally independently distributed.

Pesaran (2007) proposed a simple PURT that allows cross-sectional dependence in the data. We implement the cross-sectionally augmented IPS (CIPS) test that is known as secondgeneration PURT. The null hypothesis of CIPS test is the non-stationarity. The results of CIPS test for lag orders $p=1,2,3,4$, (Table 2) indicate that the variables in levels are non-stationary, while in first differences are stationary.

Table 1. The IPS and LLC PURTs

\begin{tabular}{ccccccccc}
\hline & \multicolumn{4}{c}{ Real GDP } & \multicolumn{3}{c}{ Real exports } \\
\hline & \multicolumn{2}{c}{ Levels } & \multicolumn{2}{c}{ FD } & \multicolumn{2}{c}{ Levels } & FD \\
\hline & Intercept & $\begin{array}{c}\text { Intercept } \\
\text { and trend }\end{array}$ & Intercept & $\begin{array}{c}\text { Intercept } \\
\text { and trend }\end{array}$ & Intercept & $\begin{array}{c}\text { Intercept } \\
\text { and trend }\end{array}$ & Intercept & $\begin{array}{c}\text { Intercept and } \\
\text { trend }\end{array}$ \\
\hline LLC & $\mathbf{- 7 . 0 7 8 5}$ & 0.261 & $\mathbf{- 1 1 . 9 3 5 4}$ & $\mathbf{- 1 5 . 6 4 8 4}$ & 0.792 & 0.2840 & $\mathbf{- 1 6 . 4 7 3 8}$ & $\mathbf{- 1 5 . 6 4 8 4}$ \\
& & & & & & & & \\
IPS & -1.2855 & -1.4483 & $\mathbf{- 1 3 . 2 8 5 2}$ & $\mathbf{- 1 1 . 6 4 2 1}$ & -2.7324 & -1.5483 & -13.2839 & $\mathbf{- 1 1 . 6 4 2 1}$ \\
\hline
\end{tabular}

Notes: Boldface values indicate rejection of the null hypothesis of $\mathrm{I}(1)$ at the $1 \%$ significant level. Lags are selected according to the Schwarz criterion.

Table 2. The CIPS PURTs

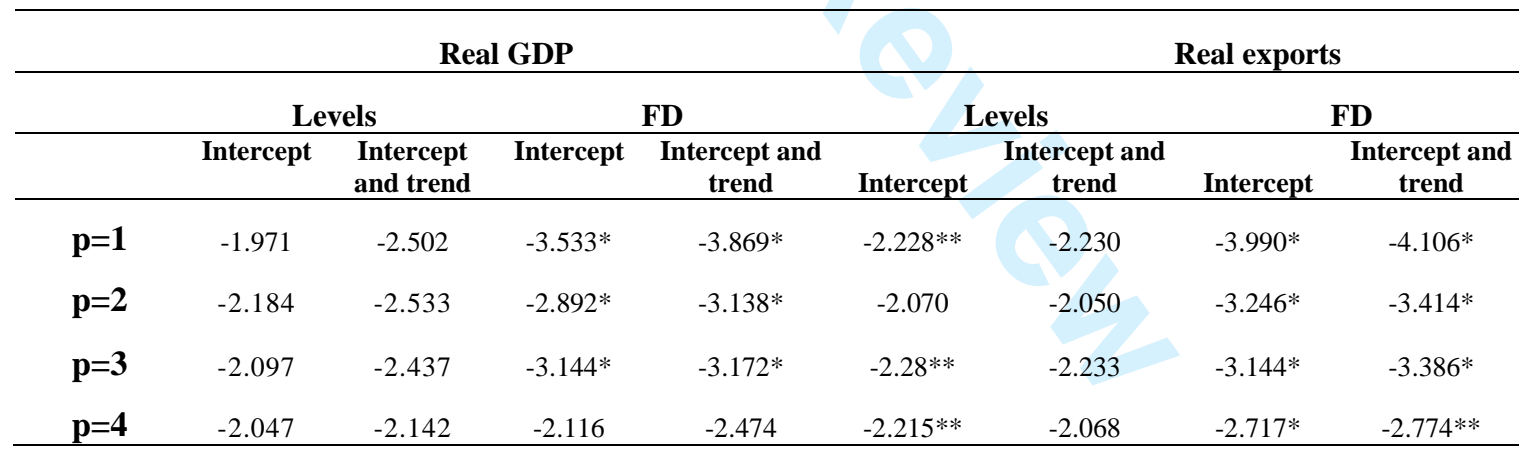

Notes: *, ** indicate rejection of the null hypothesis of I (1) at the $1 \%$ and $5 \%$ significant levels, respectively.

\subsection{Panel Cointegration}

We apply the panel cointegration tests that have been suggested by Pedroni $(1999,2004)$. These tests allow for heterogeneity in the slopes of the cointegrating equation. He proposes seven tests in which four are within-dimension (panel) and three are between-dimension (group). In all seven tests, the null hypothesis is of no cointegration. Pedroni's seven statistics are based on the estimated residuals from the panel cointegration regression. The results in Table 3 show that panel cointegration statistics provide evidence to support the existence of a long-run relation between exports and economic growth. 
Table 3. Pedroni's results

\begin{tabular}{lcc}
\hline & $\begin{array}{c}\text { Panel cointegration } \\
\text { statistics }\end{array}$ & $\begin{array}{c}\text { Group-mean panel } \\
\text { cointegration statistics }\end{array}$ \\
\hline Variance ratio & $4.2193^{*}$ & \\
PP rho-statistics & $-4.3117^{*}$ & $-4.3126^{*}$ \\
PP t-statistics & $-4.7107^{*}$ & $-4.2403^{*}$ \\
ADF statistics & $-4.6498^{*}$ & $-2.2697^{*}$ \\
\hline
\end{tabular}

Note: * indicates rejection of the null hypothesis of no cointegration at the $1 \%$ level of significance.

In addition, we conduct four panel cointegration tests that have been developed by Westerlund (2007). These tests are designed to test the null hypothesis of no cointegration by testing whether the error correction term in a conditional ECM is equal to zero. This procedure is able to handle cross-sectional dependence. The results of the Westerlund (2007) panel cointegration test are reported in Table 4 . The results provide strong evidence of cointegration.

Table 4. Westerlund's (1999) panel cointegration tests

\begin{tabular}{lcc}
\hline & Value & Robust p-value \\
\hline & $y_{i t}=\beta_{0 i}+\beta_{1 i} t+\beta_{2 i} e x_{i t}+u_{i t}$ \\
\hline$G_{T}$ & -2.401 & 0.090 \\
$G_{\alpha}$ & $-14.515^{* * *}$ & 0.013 \\
$P_{T}$ & $-8.638^{* *}$ & 0.035 \\
$P_{a}$ & $-13.637^{*}$ & 0.005 \\
\hline
\end{tabular}

Note: $*, * *$ indicates rejection of the null hypothesis of no cointegration at the $1 \%, 5 \%$ level of significance, respectively. Bootstrap replication of 800 is used to correct for cross-sectional dependence.

\subsection{Heterogeneous panel causality}

Table 5 displays the CP panel long-run causality test results. The GM based test reject the null hypothesis of no long-run Granger causality run from exports to economic growth at $10 \%$ significance level, as well as the LP test indicate the same result. Therefore, according to the results arising from the implementation of the PC methods, there is a panel long run Granger-causality run from exports to economic growth in Eurozone countries.

Table 5. Results for panel long-run causality tests for exports and economic growth

\begin{tabular}{lcccccc}
\hline & \multicolumn{2}{c}{$\lambda_{2}:$ exports $\rightarrow$ economic } & \multicolumn{2}{c}{$\lambda_{1}:$ economic growth $\rightarrow$} \\
growth & exports & \\
\hline Euro zone & Estimate & Test & p-value & Estimate & Test & p-value \\
\hline Group Mean & -0.0507 & -1.5115 & 0.0915 & -0.703 & -1.2886 & 0.3029 \\
Lambda-Pearson & & 73.601 & 0.000 & & 41.991 & 0.087 \\
\hline
\end{tabular}

Ho: No long-run causality relationship. 
To infer the sign, we estimate the long-run relationship by applying a heterogeneous panel estimator. The CMG estimator has developed by Pesaran (2006). This estimator is robust to nonstationary, cointegrated variables, and to cross-sectional correlation. Table 6 shows that the panel elasticity estimation is positive.

Table 6. Sign and coefficient (Perasan 2006). Exports independent variable and economic growth dependent variable

\begin{tabular}{lcc} 
& Coefficient & 95\% C.I. \\
\hline Exports & $0.209 *$ & {$\left[\begin{array}{ll}0.018 & 0.33\end{array}\right]$} \\
\hline Notes: C.I.: confidence interval. * at the $1 \%$ level. Statistical significance $p<0.001$.
\end{tabular}

\section{Conclusions}

This paper investigates the direction of long run causal relationship between exports and economic growth, emphasizing on heterogeneity and cross-sectional dependence. The empirical results derived from group-mean based test and lambda-Pearson based test indicated that there is positive long-run causal link running from exports to economic growth. Finally, no Grangercausality was determined to run from economic growth to exports. 


\section{References}

[1] Ahmed, J., and A.C.C. Kwan (1991) "Causality between exports and economic growth," Economics Letters 37, pp. 243-248.

[2] Balassa, B. (1978) "Export and economic growth: further evidence," Journal of Development Economics 5(2): 181-189.

[3] Bhagawati, J. N. (1988) "Export-promoting trade strategies: issues and evidence," The World Bank Research Observer, 3(1): 27-57.

[4] Bhagwati, B., and T.N. Srinivasan (1978) "Trade Policy and Development," In International Economic Policy: Theory and Evidence, edited by R. Dornbusch and J.A. Frankel, 1-38.

[5] Canning, D., and P. Pedroni (2008) "Infrastructure, long-run economic growth and causality tests for cointegrated panels," The Ma nchester School 76(5): 504-527.

[6] Feder, G. (1982) "On exports and economic growth," Journal of Development Economics 12: $59-73$.

[7] Grosssman, G.M., and E. Helpman (1991) "Trade, knowledge spillovers, and growth," European Economic Review 35: 517-526.

[8] Helpman, E., and P. Krugman (1985) Market structure and Foreign trade. Cambridge, MA: MIT Press.

[9] Im, K. S., Pesaran, M. H., and Y. Shin (2003) "Testing for unit roots in heterogeneous panels," Journal of Econometrics 115: 53-74.

[10] Jung, W.S., and P.J. Marshall (1985) "Exports, growth and causality in development countries," Journal of Development Economics 18: 1-12.

[11] Konstantakopoulou, I. (2016) "New evidence on the Export-led-growth hypothesis in the Southern Euro-zone countries (1960-2014)", Economics Bulletin, Volume 36(1): 429-439

[12] Konya, L. (2006) "Exports and growth: Granger causality analysis on OECD countries with a panel data approach," Economic Modelling 23: 978-992.

[13] Kunst, R.M., and D. Marin (1989) “On exports and productivity: A causal analysis," Review of Economics and Statistics 71: 699-703.

[14] Levin, A., Lin, C-F., and C-J. J. Chu (2002) "Unit root tests in panel data: asymptotic and finite-sample properties," Journal of Econometrics 108: 1-24.

[15] Michaely, M. (1977) "Exports and Growth," Journal of Development Economics 4: 49-53.

[16] Pedroni, P. (1999) "Critical Values for Cointegration Tests in Heterogeneous Panels with Multiple Regressors," Oxford Bulletin of Economics and Statistics 61 (special issue), 653670.

[17] Pedroni, P. (2004) "Panel cointegration: asymptotic and finite sample properties of pooled time series tests with an application to the PPP hypothesis: new results," Econometric Theory 20: 597-627.

[18] Pesaran, M.H. (2007) "A simple panel unit root test in the presence of cross-section dependefnce," Journal of Applied Econometrics 22: 265-312. 